\author{
Gennaro De Pascale \\ Massimo Antonelli
}

\section{Candida colonization of respiratory tract: to treat or not to treat, will we ever get an answer?}

Received: 3 June 2014

Accepted: 5 June 2014

Published online: 1 July 2014

(C) Springer-Verlag Berlin Heidelberg and ESICM 2014

G. De Pascale · M. Antonelli (

Istituto di Anestesiologia e Rianimazione, Università Cattolica del Sacro Cuore, Policlinico A. Gemelli Universiity Hospital, Largo A. Gemelli, 8, 00168 Rome, Italy

e-mail: m.antonelli@rm.unicatt.it

Tel.: + 390630153226

In non-immunocompromised intensive care unit (ICU) patients Candida isolation from various sites is common [1]. The association with the risk of invasive candidiasis (IC) is the rational for the use of predictive scores which include the colonization status.

However the meaning of Candida spp. recovery from the lung is definitely more intriguing. Apart from IC episodes occurring in deeply immunosuppressed subjects who may develop true fungal pneumonia, Candida respiratory tract (RT) isolation should not be considered a marker of lung infection. This issue was addressed by Meersseman et al. [2] who did not identify any autopsyproven case of Candida pneumonia among 135 autopsies with histopathological evidence of bacterial infection and high rate of Candida isolation from endotracheal aspirate (EA) and/or bronchoalveolar lavage (BAL) $(57 \%)$.

However there is growing convincing evidence, based on animal studies and human observations, that Candida spp. is not definitely an innocent bystander in the respiratory tract of ICU ventilated patients [3-13] (Table 1). Beta-glucan (BG), a component of yeast cell wall, may act as a lung proinflammatory agent causing alveolar macrophage and neutrophil dysfunction. Additionally, within the environmental biofilm there is a strong interplay, through quorum-sensing (QS) molecules, between Candida and both Gram-positive and Gram-negative bacteria [14]. Live Candida albicans instillation in rats has been observed to increase the susceptibility to develop experimental Pseudomonas aeruginosa (PA), Escherichia coli (Ec), and Staphylococcus aureus (Sa) pneumonia, fostering the production of lung inflammatory cytokines (tumor necrosis factor alpha [TNF-alpha], interleukin-6 [IL-6], and interferon-gamma [INF- $\gamma]$ ) and inhibiting alveolar macrophage phagocytosis [3, 5]. From a clinical viewpoint, Candida airway colonization has been shown to be associated with prolonged duration of mechanical ventilation, ICU/hospital length of stay, and increased mortality [8-11]. One of the first reports of this possible relationship dates back to almost 10 years ago, when Azoulay et al. [6] identified Candida bronchial isolation as an independent risk factor for the development of PA ventilator-associated pneumonia (VAP) ( 9 vs $4.8 \%$ in non-colonized patients, $p=0.048$ ). These data were strengthened just 1 year later by Nseir et al. [7] who observed a protective role of antifungal treatment on PA VAP occurrence in a cohort of patients with Candida tracheobronchial colonization. However, recently, the use of nebulized amphotericin B (NAB) was not able to provide any clinical improvement, albeit increasing the rate of Candida decolonization (adjusted HR 2.2; $95 \%$ CI 1.6-3) [13]. Hence the clinical usefulness of respiratory tract Candida colonization (CC) eradication in mechanically ventilated patients is still a matter of debate and the paper by Albert et al. [15] in the current issue of Intensive Care Medicine is the first interventional trial aiming to describe the biochemical and clinical effect of antifungal treatment in ICU patients with VAP and RT $C \mathrm{c}$. In this double-blind, placebo-controlled, multicenter study 60 patients were enrolled: 29 in the placebo group and 31 in the antifungal strategy group. A comparative 
observational cohort of 29 patients with VAP but without Candida respiratory colonization was also included. No differences between the two arms were found in any of the investigated clinical outcomes: maximum and delta Sequential Organ Failure Assessment (SOFA) score, MVand ICU-free days, subsequent ICU-acquired infections, and day-28, day-90, and hospital mortality. In addition, the inflammatory profile (TNF-alpha, IL-6, IL-8, IL-10, IL-1B, C-reactive protein [CRP], procalcitonin [PCT], intestinal fatty acid binding protein (iFABP), and lipopolysaccharide [LPS]-stimulated TNF-alpha) was similar between the antifungal and the placebo group, not being influenced by the assigned treatment. On the other hand patients harboring Candida spp. in the RT, compared with the observational group, showed higher TNF-alpha values $(21.8 \pm 23.1$ vs. $12.4 \pm 9.3 \mathrm{pg} / \mathrm{mL}, p=0.02)$ and lower LPS-induced TNF-alpha production capacity $(854.8 \pm 855.2$ vs. $1,559.4 \pm 1,290.6 \mathrm{pg} / \mathrm{mL}, p=0.01)$. Unfortunately, because of the slow enrollment rate $(0.6$ patients per month per site for the intervention groups), the trial was interrupted long before the completion of the planned sample size (120 patients for the randomized trial and 40 for the observational cohort). The authors' conclusion excluded the feasibility of a larger phase 3 trial aiming to assess the potential benefits of the antifungal treatment in patients with concomitant RT Candida spp. and VAP but some aspects of this interesting study deserve further investigation.

First, one important issue might be the choice as inclusion criteria of clinically suspected VAP (csVAP), rather than microbiologically confirmed cases. Only in 14 out of 60 randomized patients (six in the placebo arm and eight in the intervention arm) were the respiratory specimens positive for pathogenic bacteria and only two $\mathrm{Pa}$ isolates were observed.

Clinical diagnosis of VAP is challenging: in ventilated patients chest X-ray images may be frequently misleading and about $30 \%$ of ICU-acquired pneumonia remains without etiology. The authors previously described that patients with RT Candida colonization and csVAP may experience similar inflammation burden and worse outcome than patients with bacterial infections [11]. Airway Candida colonization is associated with pulmonary inflammation and consequent cellular immune dysfunction, but the role of biofilm and fungal-bacterial cross-talk should not be neglected.

Candida biofilm consists of a network of yeasts, hyphae, and/or pseudohyphae embedded in a matrix of polysaccharides, proteins, and other undefined components. This status results in the protection of the fungi

Table 1 Main animal and human studies on RT Cc and bacterial pneumonia relationship

\begin{tabular}{|c|c|c|c|}
\hline References & Study design & Study population & Main findings \\
\hline Roux et al. [3] & $\begin{array}{l}\text { Experimental animal } \\
\text { investigation }\end{array}$ & $\begin{array}{l}88 \text { Wistar rats }(70 \text { instilled with } \\
\text { Candida and } \mathrm{Pa} \text { ) }\end{array}$ & $\begin{array}{l}\text { RT } C \text { c reduced AM ROS production }(p<0.001) \text { and } \\
\text { increased Pa pneumonia prevalence }(p<0.01)\end{array}$ \\
\hline Ader et al. [4] & $\begin{array}{l}\text { Experimental animal } \\
\text { investigation }\end{array}$ & $\begin{array}{l}24 \mathrm{BALB} / \mathrm{c} \text { mice instilled with } \\
\mathrm{Pa} \text {, Candida or both }\end{array}$ & $\begin{array}{l}\text { Pa lung injury was reduced by prior RT } C \mathrm{c} \\
(p<0.05) \text {. This effect was reversed by } \\
\text { caspofungin administration }\end{array}$ \\
\hline Roux et al. [5] & $\begin{array}{l}\text { Experimental animal } \\
\text { investigation }\end{array}$ & $\begin{array}{l}200 \text { Wistar rats with RT } C \text { c }(98 \\
\text { instilled with } \mathrm{Pa} \text { or Ec or Sa) }\end{array}$ & $\begin{array}{l}\text { Previous RT } C \mathrm{c} \text { favored the development of } \mathrm{Pa}, \mathrm{Sa} \text {, } \\
\text { and Ec pneumonia }(p<0.05)\end{array}$ \\
\hline Azoulay et al. [6] & $\begin{array}{l}\text { Nested exposed/unexposed } \\
\text { study }\end{array}$ & 605 pts (211 with RT $C$ c) & $\begin{array}{l}\mathrm{CC} \text { was associated with increased Pa VAP risk (9 vs } \\
4.8 \%, p=0.04 \text { ) }\end{array}$ \\
\hline Nseir et al. [7] & $\begin{array}{l}\text { Retrospective case-control } \\
\text { study }\end{array}$ & 57 pts (19 with Pa VAP) & $\begin{array}{l}\text { Antifungal treatment reduced the risk of Pa VAP } \\
(\text { OR } 0.68,95 \% \text { CI } 0.49-0.9, p=0.046)\end{array}$ \\
\hline Delisle et al. [8] & Retrospective cohort study & 639 pts (114 with RT $C$ c) & $\begin{array}{l}\text { RT } C \text { c increased the risk of hospital mortality (RR } \\
1.63,95 \% \text { CI } 1.20-2.21, p=0.003 \text { ) }\end{array}$ \\
\hline $\begin{array}{l}\text { Williamson et al. } \\
\text { [9] }\end{array}$ & $\begin{array}{l}\text { Prospective observational } \\
\text { study }\end{array}$ & 170 pts (21 with csVAP/RT $C$ c) & $\begin{array}{l}\text { RT } C \mathrm{c} \text { in } \mathrm{csVAP} \text { was associated with lower number } \\
\text { of ICU-free days and greater mortality }(p<0.05)\end{array}$ \\
\hline $\begin{array}{l}\text { Heyland et al. } \\
\text { [10] }\end{array}$ & $\begin{array}{l}\text { Prospective observational } \\
\text { study }\end{array}$ & 57 pts (12 with csVAP/RT $C$ c) & $\begin{array}{l}\text { Trend to higher BG levels in RT } C \text { c group } \\
(p=0.09) \text {. BG positivity was associated with } \\
\text { increased } 28 \text {-day mortality }(p=0.03)\end{array}$ \\
\hline Delisle et al. [11] & $\begin{array}{l}\text { Retrospective exploratory } \\
\text { analysis }\end{array}$ & 274 pts (68 with $C$ c RT/VAP) & $\begin{array}{l}\text { Candida spp. was associated with increased hospital } \\
\text { mortality }(p<0.001)\end{array}$ \\
\hline Hamet et al. [12] & $\begin{array}{l}\text { Prospective observational } \\
\text { study }\end{array}$ & 323 pts (181 with $C \mathrm{c} \mathrm{RT} / \mathrm{csVAP})$ & $\begin{array}{l}\text { CC RT was an independent risk factor for MDR } \\
\text { bacteria isolation (OR } 1.79,95 \% \text { CI } 1.05-3.05 \\
p=0.03 \text { ) }\end{array}$ \\
\hline Ong et al. [13] & Observational cohort study & $\begin{array}{l}333 \text { episodes of RT } C \mathrm{c} \text { episodes } \\
(59 \text { received NAB) }\end{array}$ & $\begin{array}{l}\text { NAB reduced the } C \text { c RT duration by approximately } \\
3 \text { days, without any improvement in clinical } \\
\text { outcomes }\end{array}$ \\
\hline
\end{tabular}

$R T$ respiratory tract, $C C$ Candida colonization, Pa Pseudomonas aeruginosa, Sa Staphylococcus aureus, Ec Escherichia coli, AM alveolar macrophages, $R O S$ reactive oxygen species, $V A P$ ventilator-associated pneumonia, $B G$ beta-glucan, $M D R$ multidrug-resistant, $N A B$ nebulized amphotericin $\mathrm{B}$, pts patients 


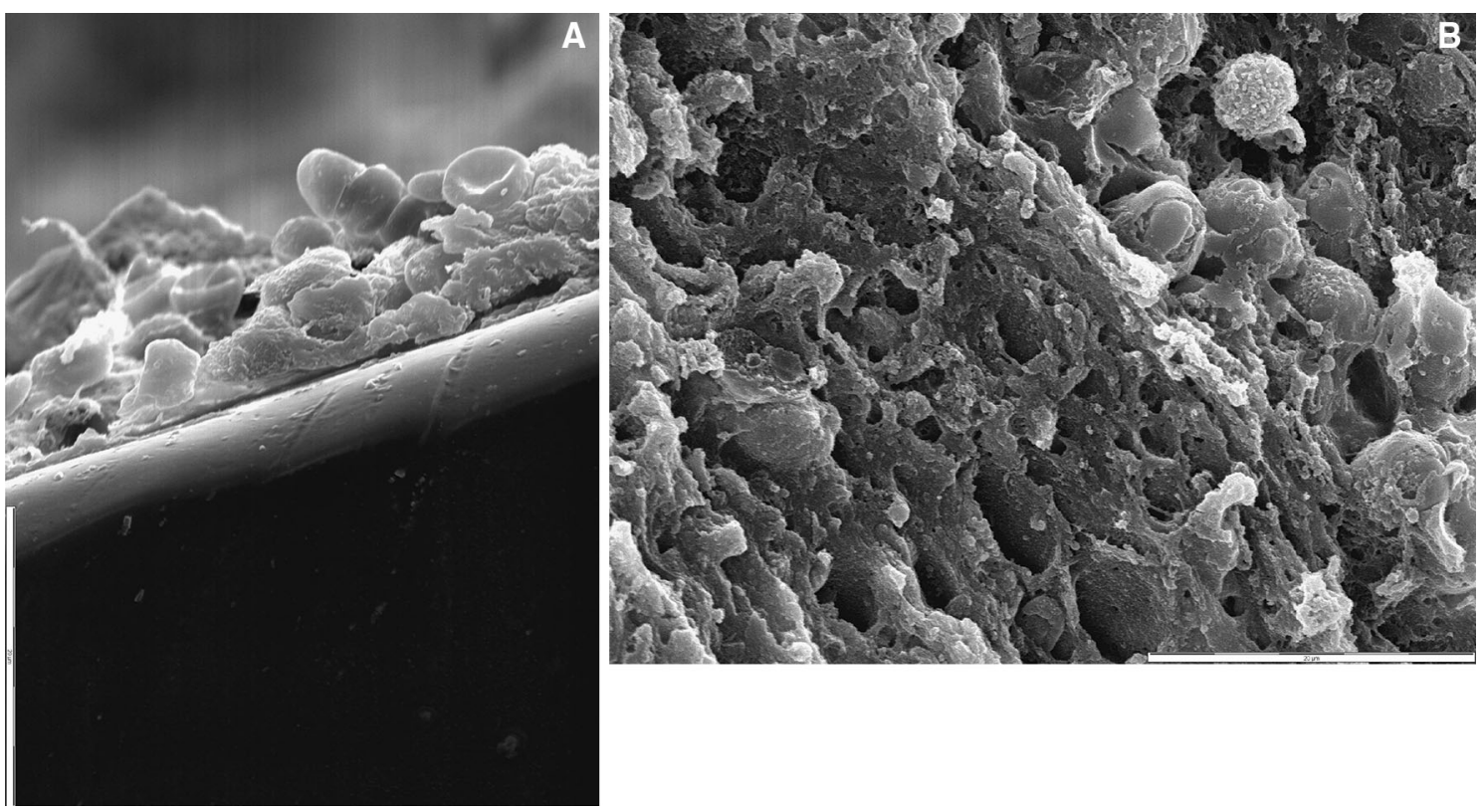

Fig. 1 Scanning electron microscopy of an uncoated endotracheal tube after extubation (a luminal surface, b bacterial biofilm) [16]

from the host defenses and the development of antifungal drug resistance. Many bacteria are able to produce biofilm and studies using electron microscopy showed that $\mathrm{Pa}$, Enterobacteriaceae (including Ec), Sa, and Candida spp. are the most common pathogens collected from artificial airways of mechanically ventilated patients (Fig. 1) [16]. Despite billions of years of cross-kingdom interaction, little is know about Candida-bacteria interactions within the biofilm. A wide range of metabolic processes and cellto-cell communications through QS molecules are the basis of both synergistic and antagonistic interactions. Interestingly, in a prospective observational study, RT Cc was identified as an independent predictor of multidrugresistant bacteria airway isolation in patients with suspected VAP [12]. As a result of the exiguous number of microbiologically confirmed VAP in the CANTREAT study, no conclusions may be drawn about these phenomena.

Second, Albert et al. [15] did not provide details on biofilm production of isolated Candida spp. A recent survey of ICU patients with IC reported in 297 Candida isolates, percentages of biofilm formation ability ranging between of 20 and $50 \%$ and higher mortality rates in patients with candidemia may be observed in the presence of high producers strains [17]. In the CANTREAT trial, patients in the intervention group received anidulafungin for a mean of $5.9 \pm 3$ days but only $22.6 \%$ were not sequentially switched to fluconazole. Unlike fluconazole, echinocandin and liposomial amphotericin $\mathrm{B}$ are highly active against both planktonic and biofilm Candida spp. but, despite the high $72 \mathrm{~h}$ Candida eradication rate, we are not aware of the potential beneficial anti-biofilm effects derived from the use of anidulafungin.

Third, the authors investigated in detail the inflammatory profile of enrolled subjects. Patients with csVAP and RT $C \mathrm{c}$ were distinctly characterized by an increased inflammatory status and a relative immunosuppression; however, this pathophysiological condition did not change over antifungal treatment, as well as BG serum levels. It is noteworthy that the average BG levels were fairly low and mainly in the range of possible false positive results [18]. In addition, the fungicidal properties of anidulafungin might have determined an early BG release from the yeast cell wall, influencing the kinetics of this biomarker and of the local/systemic inflammatory response.

Finally, the very restrictive inclusion criteria together with a relevant percentage of excluded patients (72 out $133,54.1 \%$ ) contributed to the premature interruption of the trial, which did not reach the predetermined sample size.

A definitive conclusion on the clinical relevance of respiratory tract Candida colonization has not yet been reached, and at present data are still insufficient to recommend the routine use of antifungals as decolonizing agents in non-immunocompromised patients.

Acknowledgments We thank Dr. L. Berra for providing unpublished images of Fig. 1.

Conflicts of interest The authors have no conflict of interest related to the present editorial. 


\section{References}

1. Bassetti M, Righi E, Ansaldi F, Merelli M, Cecilia T, De Pascale G, DiazMartin A, Luzzati R, Rosin C, Lagunes L, Trecarichi EM, Sanguinetti M, Posteraro B, Garnacho-Montero J, Sartor A, Rello J, Rocca GD, Antonelli M, Tumbarello M (2014) A multicenter study of septic shock due to candidemia: outcomes and predictors of mortality. Intensive Care Med 40:839-845

2. Meersseman W, Lagrou K, Spriet I, Maertens J, Verbeken E, Peetermans WE, Van Wijngaerden E (2009) Significance of the isolation of Candida species from airway samples in critically ill patients: a prospective, autopsy study. Intensive Care Med 35:1526-1531

3. Roux D, Gaudry S, Dreyfuss D, ElBenna J, de Prost N, Denamur E, Saumon G, Ricard JD (2009) Candida albicans impairs macrophage function and facilitates Pseudomonas aeruginosa pneumonia in rat. Crit Care Med 37:1062-1067

4. Ader F, Jawhara S, Nseir S, Kipnis E, Faure K, Vuotto F, Chemani C, Sendid B, Poulain D, Guery B (2011) Short term Candida albicans colonization reduces Pseudomonas aeruginosarelated lung injury and bacterial burden in a murine model. Crit Care 15:R150

5. Roux D, Gaudry S, Khoy-Ear L, Aloulou M, Phillips-Houlbracq M, Bex J, Skurnik D, Denamur E, Monteiro RC, Dreyfuss D, Ricard JD (2013) Airway fungal colonization compromises the immune system allowing bacterial pneumonia to prevail. Crit Care Med 41:e191-e199

6. Azoulay E, Timsit JF, Tafflet M, de Lassence A, Darmon M, Zahar JR, Adrie C, Garrouste-Orgeas M, Cohen Y, Mourvillier B, Schlemmer B, Outcomerea Study Group (2006) Candida colonization of the respiratory tract and subsequent pseudomonas ventilator-associated pneumonia. Chest 129:110-117
7. Nseir S, Jozefowicz E, Cavestri B, Sendid B, Di Pompeo C, Dewavrin F, Favory R, Roussel-Delvallez M, Durocher A (2007) Impact of antifungal treatment on Candida-Pseudomonas interaction: a preliminary retrospective case-control study. Intensive Care Med 33:137-142

8. Delisle MS, Williamson DR, Perreault MM, Albert M, Jiang X, Heyland DK (2008) The clinical significance of Candida colonization of respiratory tract secretions in critically ill patients. J Crit Care 23:11-17

9. Williamson DR, Albert M, Perreault MM, Delisle MS, Muscedere J, Rotstein C, Jiang X, Heyland DK (2011) The relationship between Candida species cultured from the respiratory tract and systemic inflammation in critically ill patients with ventilator-associated pneumonia. Can J Anaesth 58:275-284

10. Heyland D, Jiang X, Day AG, Laverdiere M (2011) Serum $\beta$-d-glucan of critically ill patients with suspected ventilator-associated pneumonia: preliminary observations. J Crit Care 26:536.e1-9

11. Delisle MS, Williamson DR, Albert M, Perreault MM, Jiang X, Day AG, Heyland DK (2011) Impact of Candida species on clinical outcomes in patients with suspected ventilator-associated pneumonia. Can Respir J 8:131-136

12. Hamet M, Pavon A, Dalle F, Pechinot A, Prin S, Quenot JP, Charles PE (2012) Candida spp. airway colonization could promote antibiotic-resistant bacteria selection in patients with suspected ventilator-associated pneumonia. Intensive Care Med 38:1272-1279

13. Ong DS, Mc Klein Klouwenberg P, Spitoni C, Bonten MJ, Cremer OL (2013) Nebulised amphotericin B to eradicate Candida colonisation from the respiratory tract in critically ill patients receiving selective digestive decontamination: a cohort study. Crit Care 17:R233
14. Morales DK, Hogan DA (2010) Candida albicans interactions with bacteria in the context of human health and disease. PLoS Pathog 6:e1000886

15. Albert M, Williamson D, Muscedere J, Lauzier F, Roystein C, Kanji S, Jang X, Hall M, Heyland D (2014) Candida in the respiratory tract secretions of critically ill patients and the impact of antifungal treatment: a randomised placebo-controlled pilot trial (CANTREAT study). Intensive Care Med. doi:10.1007/s00134-014-3352-2

16. Mietto C, Pinciroli R, Patel N, Berra L (2013) Ventilator associated pneumonia: evolving definitions and preventive strategies. Respir Care 58:990-1007

17. Prigitano A, Dho G, Lazzarini C, Ossi C, Cavanna C, Tortorano AM, ECMMFIMUA study group (2012) Biofilm production by Candida isolates from a survey of invasive fungal infections in Italian intensive care units. J Chemother 24:61-63

18. Posteraro B, De Pascale G, Tumbarello M, Torelli R, Pennisi MA, Bello G, Maviglia R, Fadda G, Sanguinetti M, Antonelli M (2011) Early diagnosis of candidemia in intensive care unit patients with sepsis: a prospective comparison of $(1 \rightarrow 3)$ - $\beta$-D-glucan assay, Candida score, and colonization index. Crit Care 15:R249 